\title{
Indigeneity and Blackness: Partners in the Struggles of Settler-Colonialism
}

Octavia Andrade-Dixon

\section{Introduction}

The North American continent, as it is known today, has experienced forced transformations over the past five hundred years. Through the hands of different European powers, what is known as Turtle Island by many was transformed into a radically different society. Colonizers built this territory through violent and unjust processes of dispossession and through the structural genocide of Indigenous people and the enslavement of African peoples. These processes are conceptualized as Settler-Colonialism and Trans-Atlantic Slavery. Through colonial violence, Indigenous identities have faced a barrage of Western values imposed on their everyday lives. Further, these impositions and shifts in societal structure have become internalised and therefore naturalized within Indigenous livelihood. For the descendants of slaves throughout the Americas, similar generational traumas have been enacted upon them by colonizing powers. Although the same perpetrators enacted these traumas, and in the same geographic space, they are kept separate within colonial rhetoric. However, I contest that these are not wholly separate entities, but processes that are in conversation with each other and hold strong similarities. Black and Indigenous communities are directly influenced by settler-colonial morality through the naturalization of heteropatriarchy and evangelical practises into community governance. This heteropatriarchy is then weaponized by the cis-gendered heterosexual (cishet) male population for their societal advancement and to regulate the actions of women and queer/two-spirit persons.

\section{Colonialism and Christianity}

Assimilatory practises are a method that settler-colonial states use to strip the subjects of colonization of their identity, in this instance, Indigenous and Black folk. Through residential schools, the policing of spirituality and the enforcement of colonially-acceptable governing systems, Indigenous and Black people have had to adapt and negotiate their identities as a means of survival. In turn, they have internalized these colonial moralities within their communities. Christianity is a primary tool of colonization that has been incorporated into both societies to different degrees.

Christianity was incorporated into Indigenous communities as a means of survival in the face of violent colonialism (Barker 198). Authentic forms of spirituality were repressed by colonizers. Indigenous peoples were forced to disguise their traditions within an acceptable religion as a covert means of preserving and ensuring the survival of their own cultural. However, in the current epoch, it becomes harder to differentiate between what is authentically Indigenous, and what has been naturalized. In instances such as the Diné Marriage Act, it was asserted by the Navajo Nation Council that barring same-sex marriage aligns with traditional values of the Navajo people (Barker 206). Many tribe members were shocked at this assertion and contested the view that position was compatible with their long-held values (Barker 207). From their understanding, acceptance and tolerance were the seminal values of their tribes; however, the rulings of the tribal governments were in direct opposition to this idea (Barker 209). In the Navajo nation, despite the existence of Nadleeh spirit stories that detail individuals with both masculine and feminine identities who were highly regarded in their society, they 
chose to naturalize Christianity into their spirituality instead (Barker, 212). The interpretation enforces a colonial perspective on a non-colonial governing system. The Navajo Nation Council no longer recognized that these ideals were not authentic to their people and, in its application of imposed ideals, it excluded a subset of its own people. The blurring of what is colonial and authentically Indigenous was lost in this instance.

In Black communities, the same blurring of original values and Christianity has occurred. For the "peculiar institution" to be successful, enslaved Africans were barred from practising their authentic religions. The enforcement of Christianity, coupled with the intermixing of people from different tribes and geographical areas, ensured was difficult to maintain connections to authentic modes of spirituality. Many enslaved Africans also disguised their original practices within Christian practises because it was the only way to maintain the former under plantation surveillance. Currently, Christianity is a religion that has a stronghold within the Black community, but elements of authentic spiritualities bleed through. My maternal grandmother is a devout Christian and believes certain "worldly practises" are "of the devil." Yet, she often references Obeah, an African influenced religion and medicinal practise with supernatural and natural elements, a religion that does not align with Christianity (Wisecup 411). These references are typically negative and are used to describe situations where she believes someone has directed bad energy or curses upon her, aligning with how it is used by many Jamaicans today. Despite the negative connotation, the invocation of Obeah is her acknowledgement of African spiritualities and how they are still interwoven in our cultural framework. These instances of syncretism between Christianity and authentic religions are a common thread between Black and Indigenous folk, as both groups experienced colonialism in similar ways.

\section{Weaponizing Heteropatriarchy}

The influences of Christianity on authentic governing practises manifest themselves in the ways in which men perpetuate heteropatriarchy within Black and Indigenous communities. It is disguised as beneficial but is detrimental to non-cishet male members of the community. Due to the heteropatriarchal nature of broader settler societies, men were not admonished for this behaviour by outsiders. Within Indigenous nations, heteropatriarchy has been enacted systematically at the legislative level. We see this in such practices as the marriage ban and the Indian Act.

The Cherokee National Council banned same-sex marriage on the grounds that the original Cherokee text was not gender-neutral but binary (Barker 202). However, the underlying reason was fear of settler-colonial government interference in the nation's affairs if the latter caught wind of queer indigenous people circumventing federal law (Barker 201). The council willingly excluded queer Cherokees from the legal privileges granted through marriage, because it would threaten their perceived security within settler-colonial society.

The Indian Act serves as yet another example of prioritizing male benefits. Women activists advocated for amendments to Bill C-31's Section12 (1) (b), which stripped Indigenous women and their children of their status if they had white partners (Lawrence 14). The women's efforts were not supported by male organizers, since the latter were not affected by this piece in the legislation and were more concerned that drawing attention to the Indian act would affect them detrimentally (Lawrence 14). Had it not been women fighting against male complacency, a 
large proportion of Indigenous people would not have status, leading to community alienation and inability to access resources.

Heteropatriarchal manifestations in the Black community often take place in similar spaces, such as organizing. Most notably, these practices were enacted within the civil rights movement. The most prominent names out of the Civil Rights movement were often those of men, such as Malcolm X or Martin Luther King Jr. However, bar Rosa Parks, many women were an active part of the movement but did not receive the same level of acknowledgement. Women served as integral organizers creating flyers, organizing students and working on the ground with disenfranchised community members (Barnett 168). Despite the time and labour they put into the movements, they were not allowed to be leaders because much of the civil rights movement held leaders from the church, thus ensuring a firmly male-dominated leadership space.

In Black and Indigenous communities, cishet male security is made the primary governing goal. When men in the community enact legislation or organizing tactics, it does not include the plights of all members. The notion of "community first" is a guise used to maintain the oppression of heterosexual women and queer community members. Although the thought process is gradual freedom, the reality is that men create conditional freedoms for themselves in which they find pride in functioning like cishet white men. The ability to assert dominance over the subjugated members of the community grants them the confidence they cannot find in broader society because of their marginalized positions. Thus, through the "community first" rhetoric and by weaponizing what is seen as traditional faith-based values, men are given space to perpetuate this cycle until marginalized members of the community fight for their rights at an intracommunity level.

\section{Heteropatriarchy as Regulation}

In the same way that weaponizing heteropatriarchy benefits the cishet male, it is used to the detriment of cishet women and queer individuals in Black and Indigenous communities. Within Indigenous communities, colonial laws and heteropatriarchal ideals remain unchallenged because they benefit cishet men, and allow them to maintain control over the women in their society. Through the Indian Act, Indigenous women had to be married to Indigenous men for their children to maintain status. However, men were able to intermarry and pass status to their biracial children (Lawrence15). The law allowed for men in the community to limit women's choices to only other status men because of the burden of transferring status to their children. It was also queer exclusionary, only allowing for heterosexual partnerships and erasing two-spirit identities.

When the law came under increased scrutiny and was challenged by Indigenous peoples, most activists were women. Further, once women fought back and marginally more egalitarian marriage acts were put into place, there were still heteropatriarchal tones to the legislation. Amendments to Bill C-31 did not remove the necessity of marriage from passing status but gave more room for intermarriage. Under this protocol, Indigenous women with an Indigenous mother and non-status father became 6(2)s, the lower-status denomination. This maintains the burden for former non-status women to marry a status man to prevent her children from losing status. Though this applies to male 6(2)s as well, society does not burden men with the same expectation to procreate with the same urgency it does women. Additionally, there is no mention of two-spirit or queer couples processes of childbearing, such as sperm or egg donors. How 
would their children navigate status if the biological parent was a 6(2)? This question is left unanswered with the changes.

Black women also experience the burden of maintaining the Black family. Within the Black community, racial maintenance followed an inverse process: any child who was part Black was deemed Black. This meant slave masters would sexually abuse enslaved women to create a larger labour force (Nelson). In turn, there is a strong stigma when Black women date white men. For Black men, who were fetishized differently, however, white women are objects of desire and personal advancement (Romano 130). The thought process continues currently as Black men face less scrutiny when they date white or non-white women. The expectation for Black women is that they will exclusively date Black and not "betray" the community by dating white or nonBlack. Societal pressures reveal themselves in the marriage practises of Black men and women. Black men have a $25 \%$ rate of marriage to white women, but Black women only have a $12 \%$ rate of marriage to white men (Wang).

Within my family dynamic, there have been explicitly gendered pressures to have Black partners on me and my female family members in contrast to my male family members. My Haitian grandmother, whose own mother was Italian, has vocally disapproved or expressed apprehension about the white or non-Black partners my female cousins and I have had. However, I have not heard the same sentiment when my male cousin dates white women. Despite the trauma she has dealt with due to her biracial identity, she has not extended the same warnings equally amongst her grandchildren. The pervasiveness of gendered control on Black and Indigenous women lies not only in the individual expectations of the family but in the broader landscapes of community and nation.

\section{Conclusion}

Black and Indigenous peoples have suffered at the hands of colonialism for centuries. Both people's homelands and cultures and been ravaged by European influences. As a result, the pervasive heteropatriarchal systems of colonizers have become commonplace in our communities, through modes such as religion and legal governance. Men have continuously prioritized themselves at the expense of cishet women and queer folk in our communities. The work we put in as cishet women and queer folk is not acknowledged or congratulated until we start the applause ourselves. If not for women and queer folk, many members of the community would be left to the wayside. We pick up pieces of community when no one else is willing, and through these efforts, our cultures survive. If not for the women who fought for their children to have status, many Indigenous people today would be systematically excluded from their people. If not for queer advocates, equality amongst all members would be a myth. The work of women and queer folk is what pushes us towards decolonization and staying in touch with our authentic ways rather than holding onto colonizer ways. 


\section{Works Cited}

Barker, J. (2011). Native acts law, recognition, and cultural authenticity. Durham: Duke University Press.

Barnett, B. M. (1993). Invisible Southern Black Women Leaders In The Civil Rights Movement: Gender \&amp; Society, 7(2), 162-182. doi: 10.1177/089124393007002002

Lawrence, B. (2003). Gender, Race, and the Regulation of Native Identity in Canada and the United States: An Overview. Hypatia, 18(2), 3-31. doi: 10.1353/hyp.2003.0031

Lewis, R., \& Ford-Robertson, J. (2010). Understanding the Occurrence of Interracial Marriage in the United States Through Differential Assimilation. Journal of Black Studies, 41(2), 405-420. doi: $10.1177 / 0021934709355120$

Nelson, C (2019) Exploring Slavery Through the Fugitive Slavery Archive [lecture]

Romano, R. (2018). Something Old, Something New: Black Women, Interracial Dating, and the Black Marriage Crisis. Differences, 29(2), 126-153. doi: 10.1215/10407391-6999802

UBC. "Bill C-31." Indigenousfoundations, First Nations \& Indigenous Studies UBC, 2009, https://indigenousfoundations.arts.ubc.ca/bill_c-31/.

Wang, W. (2015, June 12). Interracial marriage: Who is 'marrying out'? Retrieved from https://www.pewresearch.org/fact-tank/2015/06/12/interracial-marriage-who-is-marrying-out/.

Wisecup, K. (2013). Knowing obeah. Atlantic Studies, 10(3), 406-425. doi:

$10.1080 / 14788810.2013 .809228$ 